\title{
A specialized pollen-harvesting device in western palaearctic bees of the genus Megachile (Hymenoptera, Apoidea, Megachilidae)
}

\author{
Andreas MÜLLER*, Nicolas BANSAC \\ Institute of Plant Sciences, Applied Entomology, ETH, Clausiusstrasse 25 / NW, CH-8092 Zurich, Switzerland
}

(Received 16 May 2003; revised 18 August 2003; accepted 5 September 2003)

\begin{abstract}
Females of the European leaf-cutter bee Megachile (Megachile) pilicrus Morawitz possess a conspicuous brush of stiff, yellowish-red bristles on the ventral side of the trochanter and femur of their hind legs. Observation of pollen-harvesting females in the field and microscope analysis of scopal pollen contents revealed that the hind leg brush is a specialized device for combing pollen from the inflorescences of thistles and knapweeds (Cardueae, Asteraceae), the exclusive pollen plants of M. pilicrus. Hind leg brushes serving the same purpose were found to be also present in several Megachile species belonging to the subgenus Neoeutricharaea, indicating convergent evolution in these two different Megachile lineages. Compared to all other species, the hind leg brush of $M$. (Neoeutricharaea) apicalis is distinctly less developed which is assumed to be associated with its polylectic habit.
\end{abstract}

Megachile / Neoeutricharaea / pollen-harvesting device / Cardueae / flower specialization

\section{INTRODUCTION}

Bees feed their larvae a mixture of pollen and nectar. Many bee species exhibit floral specificity, visiting only a restricted number of plant taxa throughout their geographical range (Robertson, 1925; Michener, 1979; Westrich, 1989; Wcislo and Cane, 1996). For many of these oligolectic bees, plants of the family Asteraceae play an important role. Graenicher (1935) found that more than half of the oligoleges of a local bee fauna were associated with the Asteraceae. Similarly, over one third of all North American specialist bees are dependent on this plant family (Moldenke, 1979), and in the western palaearctic anthidiine bees, 23 of the 31 oligolectic species were found to harvest pollen on Asteraceae (Müller, 1996a). Apart from their abundance of species and their frequent occurrence in most habitats, the high pollen and nectar rewards yielded by the com- pound inflorescences of the Asteraceae over an extended time period may account for their attractiveness to oligolectic bees.

The majority of bees specializing in Asteraceae use the basitarsal brush of the (fore) legs or the abdominal scopa for pollen collection (Grinfel'd, 1962; Michener et al., 1978; Westerkamp, 1987; Westrich, 1989; Müller, 1996a). However, both basitarsal brushes and abdominal scopae did not evolve originally as pollen-harvesting tools, the former served primarily as a grooming device (Grinfel'd, 1962; Jander, 1976), the latter as a pollen transport structure (Westerkamp, 1987; Westrich, 1989). The only morphological specialization evolved for pollen collection from flowers of the Asteraceae known so far are corkscrew-like hairs on the underside of the thorax of some anthidiine bees used for wiping pollen from the flat inflorescences of some Asteraceae (Müller, 1996a).

\footnotetext{
* Corresponding author: andreas.mueller@ipw.agrl.ethz.ch
} 
The leaf-cutter bee Megachile pilicrus Morawitz, 1878 (Megachilidae) repeatedly observed to collect pollen on Asteraceae (Friese, 1899; Schmiedeknecht, 1930; Benoist, 1940; Dorn and Weber, 1988; personal observation) has long been known to possess a conspicuous brush of stiff, yellowish-red bristles on the ventral side of the trochanter and femur of the hind legs. The function of this structure is still unknown, but it is used as a reliable character in determination keys (Friese, 1899; Schmiedeknecht, 1930; Benoist, 1940; Dorn and Weber, 1988; Scheuchl, 1996). The fact that the specialized pilosity was found to be densely filled with pollen grains in many females collected renders it highly probable that the hind leg brush is a morphological adaptation for pollen collection.

The aim of this study was to examine the hypothesis that the hind leg brush of $M$. pilicrus is used for pollen removal from the flower heads of Asteraceae, and to search for other western palaearctic Megachile species equipped with a similar specialized device.

\section{MATERIALS AND METHODS}

\subsection{Occurrence of hind leg brushes in the genus Megachile}

We examined the females of about 60 western palaearctic Megachile species belonging to all subgenera (according to Michener, 2000) under a dissecting microscope to find species other than M. pilicrus equipped with a hind leg brush. In contrast to Michener (2000), we retain Eutricharaea Thomson, 1872 and Neoeutricharaea Rebmann, 1967 as different subgenera. M. rubrimana auct. is treated here as a synonym of $M$. flabellipes Pérez, 1895 (Alfken, 1924; Gogala, 1999). For elucidating the phylogenetic relationships of the Megachile species concerned we consulted Rebmann (1967), Dorn and Weber (1988), Rasmont et al. (1995), Schwarz et al. (1996), and Michener (2000). Information on the number of species in the different subgenera of Megachile was drawn from the same publications and from Zanden (1986, 1992, 1996).

\subsection{Structure of the hind leg brush}

A scanning electron microscope was used to compare the hind leg brushes of the different $\mathrm{Meg}$ achile species.

\subsection{Pollen-harvesting behaviour}

We recorded the pollen-harvesting behaviour of several females of M. pilicrus in the field using a threefold magnifying lens. The field observations took place in the Abruzzo mountains in central Italy in August 2002. In addition, we analyzed photographs of flower-visiting females of $M$. flabellipes taken in the valley of Aosta in northern Italy in July 1996.

\subsection{Pollen sources}

To assess the pollen plants of the Megachile species equipped with a hind leg brush, we analyzed the scopal contents of females from museum and private collections by light microscopy using the method outlined by Westrich and Schmidt (1986). Before removing pollen from the female bees, we estimated the degree to which the abdominal scopae were filled. We assigned the amount of pollen to five classes ranging from $5=$ full load to $1=$ scopa onefifth filled. After removing surface lipids by washing in ether, the pollen was embedded in glycerine gelatine on a slide. We estimated the percentages of different pollen types by counting the grains along four lines chosen randomly across the cover slip at a magnification of 400x. Pollen types represented by less than $5 \%$ of the counted grains were not considered to prevent biases caused by contamination. After assigning different weights to scopae according to how filled they were (full loads were five times more strongly weighted than scopae filled only to one fifth), we summed up the estimated percentages over all investigated samples of each species. We identified the pollen grains at a magnification of $400 \times$ or $1000 \times$ with the aid of the literature cited in Westrich and Schmidt (1986) and a reference collection consisting of pollen samples of more than 500 plant species. Pollen grains were identified down to family level, those of the Asteraceae down to subfamily or tribe level. The classification of the Asteraceae follows Bremer (1994). We examined 45 pollen loads of $M$. pilicrus, 30 pollen loads each of $M$. apicalis and $M$. flabellipes, 6 pollen loads of M. melanogaster, and 4 pollen loads of M. picicornis. The pollen samples of $M$. pilicrus originated from Switzerland (19 samples), Italy (14), France (7), Austria (2), Hungary (1), Serbia (1) and Spain (1). Pollen samples of $M$. apicalis originated from Italy (9), Morocco (6), Spain (6), Greece (3), Croatia (2), France (2) and Switzerland (2). Samples of M. flabellipes were from Italy (20), Switzerland (6) and Croatia (4). Samples of M. melanogaster were from Italy (4) and Spain (2), and those of M. picicornis were from Morocco (2), Algeria (1) and Libya (1). 


\section{RESULTS}

\subsection{Occurrence of hind leg brushes in the genus Megachile}

M. pilicrus Morawitz, 1878 is not the only western palaearctic leaf-cutter bee with a conspicuous brush of stiff bristles on the ventral side of the trochanter and femur of the hind legs. We found the same structure also to be present in the following species: M. apicalis Spinola, 1808, M. flabellipes Pérez, 1879, M. flavidus Zanden, 1998, M. kruegeri Friese, 1923, M. melanogaster Eversmann, 1852, and M. picicornis Morawitz, 1853. According to the species description, M. sexmaculata Alfken, 1942 is a further species with specialized hind leg pilosity (Alfken, 1942).

On the basis of their morphology and according to the literature, the systematic positions of these species are well substantiated. M. pilicrus is a typical representative of the subgenus Megachile Latreille, 1802, whereas the other species all belong to the subgenus Neoeutricharaea Rebmann, 1967. M. flavidus was described by Zanden (1998) as a subspecies of $M$. pilicrus. On closer morphological inspection, however, M. flavidus turned out to be different from $M$. pilicrus belonging to the subgenus Neoeutricharaea and not to Megachile. In summary, one of the at least 11 western palaearctic species of the subgenus Megachile and seven of the roughly 20 species of Neoeutricharaea were found to be equipped with a hind leg brush.

\subsection{Structure of the hind leg brush}

In M. pilicrus, the ventral surface of the trochanter and femur of the hind legs is densely beset with stiff, yellowish-red bristles tapering towards the apex and slightly wavy in the uppermost part (Fig. 1a, 1b, 1c). The specialized pilosity covers the whole trochanter and the basal two thirds of the femur while the apical third is hairless. When femur and tibia are moved towards each other, the specialized pilosity on the ventral side of the femur comes in contact with the inner surface of the tibia which is mostly hairless except on its apical fifth and along its outer longitudinal border where the same type of specialized bristles are developed. The inner longitudinal border is loosely beset with rather short hairs.

Localization and structure of the specialized pilosity in the different species of the subgenus Neoeutricharaea are the same as in M. pilicrus (Fig. 1d). Apart from the hair colour, which, depending on the species, varies from whitish and yellowish to brownish, the hind leg brushes are surprisingly similar to that of $M$. pilicrus. $M$. apicalis is an exception. Compared to all other species, the density of the specialized bristles on both the trochanter and femur is distinctly less (Fig. 1e).

In Megachile and Neoeutricharaea species lacking a hind leg brush the trochanter bears normal setae and the ventral side of the femur is naked or at most loosely beset with short and thin hairs (Fig. 1f).

\subsection{Pollen-harvesting behaviour}

The field observation of pollen-harvesting females of M. pilicrus on Centaurea calcitrapa L. and C. solstitialis L. (Asteraceae, Cardueae) revealed that the hind leg brush is indeed used for pollen removal from Cardueae inflorescences. All females were observed to collect pollen in exactly the same manner: after landing on the flower head the female bee embraced a few neighbouring flowers with the hind leg, squeezed them between femur and tibia and pulled the leg upwards over the pollen-bearing styles thereby combing the pollen grains into the specialized hind leg pilosity. The rapid movements of embracing, squeezing and pulling were performed alternately with each hind leg. During the process of pollen collection, the bee slowly crawled over the flower head using its fore and mid legs, constantly inserting the proboscis into new flowers for nectar uptake. The abdomen was held steeply upwards all the time allowing the hind legs to move freely. After having worked a flower head, the female flew up and hovered for a few seconds nearby. The transfer of the pollen grains from the hind leg brush to the abdominal scopa most probably took place during hovering as could be judged from the rapid movements performed by all legs. The exact manner in which pollen grains are transferred to the scopa could not be ascertained however.

The analysis of photographs of pollen-collecting females of M. flabellipes on Centaurea 

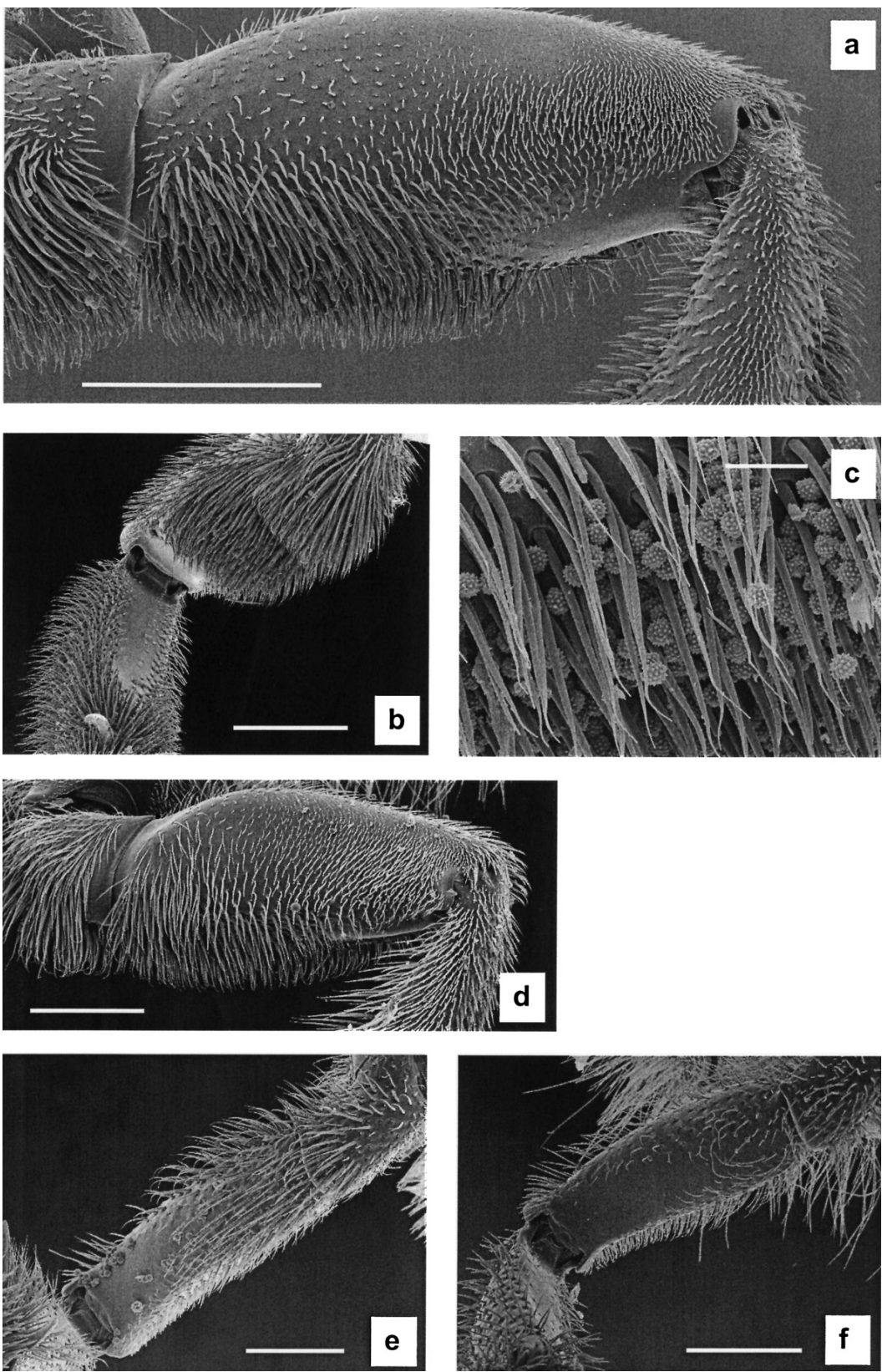

Figure 1. Megachile (Megachile) pilicrus: (a) Hind leg brush on ventral side of trochanter and femur as seen from behind (scale bar $=800 \mu \mathrm{m}$ ). (b) Hind leg brush and inner surface of the tibia as seen from below (scale bar $=800 \mu \mathrm{m}$ ). (c) Specialized bristles of hind leg brush filled with pollen grains of the Serratula type (scale bar $=100 \mu \mathrm{m}$ ). Megachile (Neoeutricharaea) flabellipes: (d) Hind leg brush on ventral side of trochanter and femur as seen from behind (scale bar $=600 \mu \mathrm{m}$ ). Megachile (Neoeutricharaea) apicalis: (e) Hind leg brush on ventral side of trochanter and femur as seen from below (scale bar $=500 \mu \mathrm{m})$. Megachile (Neoeutricharaea) rotundata: (f) Ventral side of trochanter and femur of hind leg as seen from below (scale bar = $500 \mu \mathrm{m})$. 


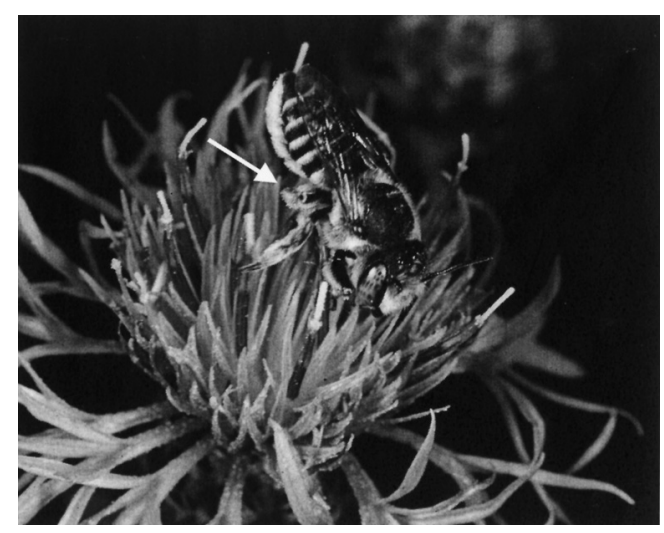

Figure 2. Pollen-harvesting female of Megachile (Neoeutricharaea) flabellipes on Centaurea paniculata. Aosta Valley (Italy), July 1996. As indicated by the arrow, femur and tibia of the right hind leg are in close contact with each other, most probably squeezing a single flower between them.

Table I. Composition of scopal pollen contents of five Megachile species equipped with a hind leg brush. Designation of the Cardueae pollen types according to Zander (1935).

\begin{tabular}{|c|c|c|c|c|c|c|c|c|c|c|}
\hline & \multicolumn{3}{|c|}{ Asteraceae, Cardueae } & \multirow{2}{*}{$\begin{array}{l}\text { other } \\
\text { Aster- } \\
\text { aceae }\end{array}$} & \multirow{2}{*}{$\begin{array}{l}\text { Lami- } \\
\text { aceae }\end{array}$} & \multirow{2}{*}{$\begin{array}{l}\text { Fab- } \\
\text { aceae }\end{array}$} & \multirow{2}{*}{$\begin{array}{l}\text { Brassic- } \\
\text { aceae }\end{array}$} & \multirow{2}{*}{$\begin{array}{l}\text { Resed- } \\
\text { aceae }\end{array}$} & \multirow{2}{*}{$\begin{array}{l}\text { Mimos- } \\
\text { aceae }\end{array}$} & \multirow{2}{*}{$\begin{array}{c}\text { un- } \\
\text { known }\end{array}$} \\
\hline & $\begin{array}{l}\text { Centaurea } \\
\text { jacea type }\end{array}$ & $\begin{array}{l}\text { Serra- } \\
\text { tula type }\end{array}$ & $\begin{array}{c}\text { Jurinea } \\
\text { type }\end{array}$ & & & & & & & \\
\hline $\begin{array}{l}\text { M. pilicrus } \\
(\mathrm{n}=45)\end{array}$ & $98.5 \%$ & $0.8 \%$ & $0.7 \%$ & & & & & & & \\
\hline $\begin{array}{l}\text { M. apicalis } \\
(\mathrm{n}=30)\end{array}$ & $68.6 \%$ & $7.6 \%$ & & $2.3 \%$ & $10.7 \%$ & $6.8 \%$ & $2.5 \%$ & $0.8 \%$ & $0.2 \%$ & $0.5 \%$ \\
\hline $\begin{array}{l}\text { M. flabellipes } \\
(\mathrm{n}=30)\end{array}$ & $100 \%$ & & & & & & & & & \\
\hline $\begin{array}{l}\text { M. melanogaster } \\
(\mathrm{n}=6)\end{array}$ & $100 \%$ & & & & & & & & & \\
\hline $\begin{array}{l}\text { M. picicornis } \\
(\mathrm{n}=4)\end{array}$ & $28.6 \%$ & $71.4 \%$ & & & & & & & & \\
\hline
\end{tabular}

paniculata L. indicates that this species uses its hind leg brush in the same way as M. pilicrus: in two photographs, femur and tibia of the hind leg can be seen to be in close contact to each other, most probably squeezing a single flower between them (Fig. 2).

\subsection{Pollen sources}

All pollen samples of $M$. pilicrus, $M$. flabellipes, M. melanogaster and $M$. picicornis consisted exclusively of pollen of the Cardueae (knapweeds and thistles), a tribe of the Asteraceae (Tab. I, Fig. 2). While M. picicornis was found to use thistles (pollen of the "Serratula type") to a considerable degree, the other three species seem to collect pollen exclusively or predominantly on knapweeds (Centaurea). M. apicalis turned out to be polylectic, harvesting pollen on six different plant families. Pollen of the Cardueae was represented by $76.2 \%$ of the counted pollen grains, however, rendering this plant tribe the most important pollen source for M. apicalis.

\section{DISCUSSION}

Our findings clearly support the hypothesis that the hind leg brush of $M$. pilicrus is a morphological adaptation for pollen removal from the flower heads of Asteraceae. Though the 
exact pollen-harvesting behaviour of the Neoeutricharaea species could not be observed in the field, we strongly assume the specialized hind leg pilosity to have the same function in this subgenus as in M. pilicrus. This is supported by the morphological similarity of the specialized pilosity and its identical localization, by the same preferred pollen sources, and by the analysis of photographs of pollen-collecting females.

In general, morphological specializations for pollen harvesting are rarely found in bees (Thorp, 1979, 2000; Westerkamp, 1987; Westrich, 1989; Wcislo and Cane, 1996). With few exceptions, specialized pollen-collecting devices are known at present to occur in bees exploiting one of the following flower types: (1) nototribic flowers where the raised position of the anthers renders an efficient collection of pollen difficult (Müller, 1996b; Houston, 2000; Thorp, 2000), (2) flowers where the anthers are concealed within narrow tubes (Müller, 1995; Thorp, 2000; Müller and Kuhlmann, 2003), and (3) flowers of small size packed in dense inflorescences where the separate exploitation of each flower is inefficient (Müller, 1996a). The pollen-collecting device of Megachile described in the present publication fits in the third category though an efficient collection of pollen from the inflorescences of Cardueae is also possible without a hind leg brush. At our observation sites in the Abruzzo mountains, females of M. (Megachile) melanopyga Costa, 1863 and M. (Megachile) octosignata Nylander, 1852 , both close relatives of $M$. pilicrus, were observed to use their abdominal scopa for removing pollen from Centaurea. In both species, the hind legs embraced several flowers and guided them under the abdomen while the latter was permanently performing rapid up and down movements, thereby bringing the scopal hairs in contact with the pollen grains sticking to the styles. In the field, pollen-harvesting females of these two species could be distinguished from those of $M$. pilicrus from some distance as they hold their abdomen much less steeply compared to M. pilicrus (see Results). Many anthidiine and osmiine bees are known to collect pollen on Cardueae inflorescences in much the same way as M. melanopyga and $M$. octosignata (Westerkamp, 1987; Westrich, 1989; Müller, 1994, 1996a).
The analysis of scopal pollen contents revealed that Megachile species equipped with a hind leg brush collect pollen exclusively or predominantly on Cardueae. Though no pollen samples were available for $M$. flavidus, $M$. krïgeri and $M$. sexmaculata, we expect these species to be oligoleges or near oligoleges of Cardueae as well. With the exception of $M$. pilicrus, M. lapponica (specialized on Epilobium (Onagraceae)), and M. genalis (probably oligolectic on Asteraceae), the European leafcutter bees of the subgenus Megachile are polylectic (Westrich, 1989). M. genalis and all polylectic species including $M$. melanopyga and $M$. octosignata (see above) are known to harvest some of their pollen from Cardueae (Benoist, 1940; Dorn and Weber 1988; Westrich, 1989). In contrast, no flower or pollen records from Cardueae are known so far for the leafcutter bees of the subgenus Neoeutricharaea which lack a hind leg brush. M. rotundata (Fabricius, 1784) is polylectic harvesting pollen from at least six different plant families including Asteraceae but not Cardueae (Westrich, 1989; Rust et al., 2003), whereas both M. burdigalensis Benoist, 1940 and M. deceptoria Pérez, 1890 were observed to collect pollen mainly from Fabaceae (Benoist, 1940; Dorn and Weber, 1988; Gogala, 1998, 1999), the latter also on Cucurbitaceae (Rust et al., 2003).

Hind leg brushes were found to occur in two lineages of Megachile. Therefore, they must have independently evolved at least twice in the leaf-cutter bees. Interestingly, no clear differences could be found in the localization or in the structure of the specialized pilosity between M. pilicrus and the Neoeutricharaea species. An exception is M. apicalis whose hind leg brush is distinctly less developed than that of all the other species. Though it shows a clear preference for Cardueae, we found $M$. apicalis to use many other pollen sources as well. This finding is confirmed by Benoist (1940), Dorn and Weber (1988) and Westrich (1989) who observed M. apicalis collecting pollen on Asteraceae, Fabaceae and Apiaceae. This suggests that the weaker hind leg brush is associated with the polylectic habit. The question then arises whether in M. apicalis a shift from oligolecty to polylecty has occurred with a corresponding reduction in the hind leg brush or whether this species is on its way to becoming a specialist of Cardueae thereby developing a 
new brush. As the polylectic habit was found to be the derived state in many bee lineages (Kratochwil, 1984; Westerkamp, 1987; Westrich, 1989; Müller, 1996a; Michener, 2000), we hypothesize that the ancestors of $M$. apicalis were oligoleges of Cardueae and that parallel to the shift to polylecty the hind leg brush of $M$. apicalis was reduced. Only a cladistic analysis would allow a test of this hypothesis. However, due to the poor taxonomic and systematic state of knowledge on the palaearctic Megachile species, such an analysis seems premature.

\section{ACKNOWLEDGEMENTS}

We thank Dr. B. Merz (Muséum d'histoire naturelle Genève), Dr. C. Huber (Naturhistorisches Museum Bern), Dr. L. Reser (Naturmuseum Luzern), Dr. D. Burckhardt (Naturhistorisches Museum Basel), Dr. E. Steinmann (Chur) and F. Amiet (Solothurn) for allowing us to remove pollen samples from bee specimens under their curation, Dr. P. Hartmann (University of Bayreuth) for the loan of a female of Megachile flavidus and for discussions regarding the systematics and nomenclature of Megachile, U. Jauch (Institute for Botany, University of Zurich) for help with the scanning electron microscope, Dr. Kathrin Tschudi-Rein (ETH Zurich) for correcting the English, and Prof. Dr. Silvia Dorn (ETH Zurich), Dr. Bernard E. Vaissière (INRA, Avignon) and two anonymous reviewers for helpful comments on earlier drafts of the manuscript.

Résumé - Un dispositif spécialisé dans la récolte du pollen chez des abeilles paléarctiques occidentales du genre Megachile (Hymenoptera, Apoidea, Megachilidae). Les abeilles nourrissent leurs larves avec un mélange de pollen et de nectar. Alors que l'on connaît de nombreuses adaptations morphologiques pour la récolte du nectar, les équipements morphologiques spécialisés pour la récolte du pollen sont restreints aux espèces d'abeilles qui (1) récoltent le pollen sur les fleurs où les anthères sont en position élevée, (2) exploitent les fleurs dont les anthères sont cachées à l'intérieur de tubes étroits ou (3) visitent les fleurs qui sont disposées en inflorescences serrées.

Les femelles de l'abeille européenne Megachile (Megachile) pilicrus Morawitz possèdent sur la partie inférieure du trochanter et du fémur des pattes postérieures une brosse épaisse spectaculaire de soies raides de couleur rouge jaunâtre, dont la fonction est inconnue (Fig. $1 \mathrm{a}-\mathrm{c}$ ). Le fait que les brosses des pattes postérieures soient souvent densément remplies de pollen chez les femelles qui butinent laisse à penser qu'il s'agit là d'une adaptation morphologique spécialisée dans la récolte du pollen. Nous avons vérifié cette hypothèse en observant sur le terrain des femelles butinant des fleurs et en analysant au microscope les charges de pollen de ces insectes. Nous avons aussi recherché, chez environ 60 autres espèces ouest-paléarctiques de mégachiles, la présence de brosses semblables sur les pattes postérieures.

L'observation de butineuses de pollen de $M$. pilicrus dans la région des Abruzzes (Italie) a montré que les brosses des pattes postérieures servaient à récolter le pollen des centaurées et des chardons (Cardueae). Les femelles entourent quelques fleurs avec une patte postérieure, les pressent entre le fémur et le tibia et tirent la patte refermée vers l'arrière et le haut au-dessus des styles porteurs de pollen, puis elles peignent les grains de pollen et les font s'accrocher dans la pilosité spécialisée de la patte postérieure. Ces mouvements sont effectués alternativement par chaque patte postérieure. La relation étroite de M. pilicrus avec les représentants des Cardueae a été prouvée par l'analyse microscopique de nombreuses charges polliniques récoltées par les femelles dans diverses régions d'Europe.

Les brosses des pattes postérieures ont été également étudiées chez sept espèces de Megachile du sousgenre Neoeutricharaea. Elles ont dû évoluer chez les abeilles du genre Megachile indépendamment au moins à deux reprises. La position identique et la structure semblable des soies spécialisées (Fig. 1 de), ainsi que le fait que toutes les espèces de $\mathrm{Neoeu}$ tricharaea étudiées récoltent uniquement ou de préférence le pollen des Cardueae, font conclure que les brosses des pattes postérieures possèdent la même fonction que celle de M. pilicrus. M. (Neoeutricharaea) apicalis se distingue de toutes les autres espèces étudiées par le développement plus faible de la pilosité spécialisée. Elle est aussi la seule espèce étudiée qui exploite, outre les Cardueae, de plantes de nombreuses autres familles botaniques (Tab. I).

\section{Megachile / Neoeutricharaea / adaptation morphologique / récolte de pollen / Cardueae / spécialisation florale}

Zusammenfassung - Ein spezialisierter Pollensammelapparat bei westpaläarktischen Bienen der Gattung Megachile (Hymenoptera, Apoidea, Megachilidae). Bienen ernähren ihre Larven mit einem Gemisch aus Nektar und Pollen. Während zahlreiche morphologische Anpassungen für die Nektaraufnahme bekannt sind, beschränken sich spezialisierte morphologische Pollensammeleinrichtungen auf Bienenarten, die (1) Pollen auf Blüten mit oberständigen Antheren sammeln, (2) Blüten ausbeuten, welche die Antheren im Innern enger Kronröhren verborgen haben, oder (3) Blüten besuchen, die in dichten Blütenständen angeordnet sind. Die Weibchen der europäischen Blattschneiderbiene Megachile (Megachile) pilicrus Morawitz besitzen auf der Unterseite von Trochanter und Femur der Hinterbeine eine auffällige dichte Bürste aus steifen, gelblich-rot gefärbten Borsten, deren 
Funktion unbekannt ist (Abb. 1 a-c). Die Tatsache, dass die Hinterbeinbürsten bei gesammelten Weibchen vielfach dicht mit Pollen gefüllt sind, spricht dafür, dass es sich dabei um eine spezialisierte Pollensammeleinrichtung handelt. Wir prüften diese Hypothese mit der Beobachtung blütenbesuchender Weibchen im Feld und mit mikroskopischen Analysen der Pollenladungen gesammelter Tiere. Zusätzlich untersuchten wir rund 60 weitere westpaläarktische Megachile-Arten auf das Vorhandensein von vergleichbaren Hinterbeinbürsten.

Die Beobachtung pollensammelnder Weibchen von M. pilicrus im Gebiet der Abruzzen (Italien) zeigte, dass die Hinterbeinbürste dazu dient, Pollen von Flockenblumen und Disteln (Asteraceae, Cardueae) zu ernten. Die Weibchen umfassen dazu einige Blüten mit einem Hinterbein, klemmen sie zwischen Femur und Tibia ein und ziehen das geschlossene Bein nach hinten-oben über die pollentragenden Griffel der Einzelblüten, wobei die Pollenkörner in die spezialisierte Behaarung der Hinterbeine gekämmt werden. Das Auskämmen erfolgt mit alternierenden Bewegungen beider Hinterbeine. Die strenge Bindung von M. pilicrus an Vertreter der Cardueae wird durch die mikroskopische Analyse zahlreicher Pollenladungen gesammelter Weibchen aus unterschiedlichen Gebieten Europas belegt.

Hinterbeinbürsten wurden auch bei sieben Megachile-Arten der Untergattung Neoeutricharaea gefunden. Sie dürften in der Gattung Megachile somit mindestens zweimal konvergent entstanden sein. Die identische Lage und der gleiche Bau der spezialisierten Borsten (Abb. 1 d-e) sowie die Tatsache, dass alle untersuchten NeoeutricharaeaArten Pollen auschliesslich oder bevorzugt auf Cardueae sammeln, lassen den Schluss zu, dass die Hinterbeinbürsten hier dieselbe Funktion besitzen wie bei M. pilicrus. M. (Neoeutricharaea) apicalis unterscheidet sich von allen andern untersuchten Arten durch die schwächere Ausbildung der spezialisierten Behaarung. Sie ist gleichzeitig die einzige untersuchte Art, welche neben Vertretern der Cardueae auch Pflanzen aus zahlreichen weiteren Verwandtschaftskreisen für die Pollenaufnahme nutzt (Tab. I).

\section{Megachile / Neoeutricharaea / Pollensammelap- parat / Flockenblumen und Disteln / Blütenspe- zialisierung}

\section{REFERENCES}

Alfken J.D. (1924) Zur Kenntnis einiger Arten der Megachile argentata-Gruppe, Acta Mus. Dziedusz. 9, 86-91.

Alfken J.D. (1942) Beiträge zur Kenntnis paläarktischer Bienen, Veröff. Überseemus. Bremen 3, 206-216.
Benoist R. (1940) Remarques sur quelques espèces de Mégachiles principalement de la faune française, Ann. Soc. Entomol. Fr. 109, 41-88.

Bremer K. (1994) Compositae. Cladistics and classification, Timber Press, Portland, Oregon.

Dorn M., Weber D. (1988) Die Luzerne-Blattschneiderbiene und ihre Verwandten in Mitteleuropa, Neue Brehm-Bücherei, No. 582, Ziemsen, Wittenberg Lutherstadt.

Friese H. (1899) Die Bienen Europas (Apidae europaeae). Teil V. Solitäre Apiden: Genus Lithurgus, Genus Megachile (Chalicodoma), Lampe, Innsbruck.

Gogala A. (1998) The identity of Megachile dorsalis Pérez and Megachile burdigalensis Benoist, sp. rev. (Hymenoptera: Apoidea: Megachilidae), Acta Entomol. Slov. 6, 79-87.

Gogala A. (1999) Bee fauna of Slovenia: checklist of species (Hymenoptera: Apoidea), Scopolia 42, 179.

Graenicher S. (1935) Bee-fauna and vegetation of Wisconsin, Ann. Entomol. Soc. Am. 28, 285-310.

Grinfel'd E.K. (1962) Origin and development of the apparatus for pollen collection in bees (Hymenoptera: Apoidea), Entomol. Rev. 41, 37-42.

Jander R. (1976) Grooming and pollen manipulation in bees (Apoidea): the nature and evolution of movements involving the foreleg, Physiol. Entomol. 1, 179-194.

Houston T.F. (2000) Native bees on wildflowers in western Australia. A synopsis of bee visitation of wildflowers based on the bee collection of the Western Australian Museum, Special publication No. 2, Western Australian Insect Study Society, Perth.

Kratochwil A. (1984) Pflanzengesellschaften und Blütenbesucher-Gemeinschaften: biozönologische Untersuchungen in einem nicht mehr bewirtschafteten Halbtrockenrasen (Mesobrometum) im Kaiserstuhl (Südwestdeutschland), Phytocoenologia 11, 455-669.

Michener C.D. (1979) Biogeography of the bees, Ann. Miss. Bot. Gard. 66, 277-347.

Michener C.D. (2000) The bees of the world, Johns Hopkins University Press, Baltimore and London.

Michener C.D., Winston M.L., Jander R. (1978) Pollen manipulation and related activities and structures in bees of the family Apidae, Univ. Kans. Sci. Bull. 51, 575-601.

Moldenke A.R. (1979): Host-plant coevolution and the diversity of bees in relation to the flora of North America, Phytologia 43, 357-419.

Müller A. (1994) Die Bionomie der in leeren Schneckengehäusen nistenden Biene Osmia spinulosa, Veröff. Naturschutz Landschaftspl. Bad.-Württ. 68/69, 291-334.

Müller A. (1995) Morphological specializations in Central European bees for the uptake of pollen 
from flowers with anthers hidden in narrow corolla tubes (Hymenoptera: Apoidea), Entomol. Gen. 20, 43-57.

Müller A. (1996a) Host-plant specialization in western palearctic anthidiine bees (Hymenoptera: Apoidea: Megachilidae), Ecol. Monogr. 66, 235-257.

Müller A. (1996b) Convergent evolution of morphological specializations in Central European bee and honey wasp species as an adaptation to the uptake of pollen from nototribic flowers (Hymenoptera, Apoidea and Masaridae), Biol. J. Linn. Soc. $57,235-252$.

Müller A., Kuhlmann M. (2003) Narrow flower specialization in two European bee species of the genus Colletes (Hymenoptera, Apoidea, Colletidae), Eur. J. Entomol. 100, 631-635.

Rasmont P., Ebmer P.A., Banaszak J., Zanden G. van der (1995) Hymenoptera Apoidea Gallica. Liste taxonomique des abeilles de France, de Belgique, de Suisse et du Grand-Duché de Luxembourg, Bull. Soc. Entomol. Fr. 100 (hors série), 1-98.

Rebmann O. (1967) Beitrag zur Kenntnis der Gattung Megachile Latr. (Hym., Apidae): Subgenus Eutricharaea Thoms. und Neoeutricharaea nov. subg., Entomol. Z. 77, 33-38.

Robertson C. (1925) Heterotropic bees, Ecology 6, 412-436.

Rust R.W., Vaissière B.E., Westrich P. (2003) Pollinator biodiversity and floral resource use in Ecballium elaterium (Cucurbitaceae), a Mediterranean endemic, Apidologie 34, 29-42.

Scheuchl E. (1996) Illustrierte Bestimmungstabellen der Wildbienen Deutschlands und Österreichs. Band II: Megachilidae - Melittidae, Eigenverlag, Velden.

Schmiedeknecht O. (1930) Die Hymenopteren Nordund Mitteleuropas, 2nd ed., Fischer, Jena.

Schwarz M., Gusenleitner F., Westrich P., Dathe H.H. (1996) Katalog der Bienen Österreichs, Deut- schlands und der Schweiz (Hymenoptera, Apidae), Entomofauna, Suppl. 8.

Thorp R.W. (1979) Structural, behavioral, and physiological adaptations of bees (Apoidea) for collecting pollen, Ann. Miss. Bot. Gard. 66, 788-812.

Thorp R.W. (2000) The collection of pollen by bees, Plant Syst. Evol. 222, 211-223.

Wcislo W.T., Cane J.H. (1996) Floral resource utilization by solitary bees (Hymenoptera: Apoidea) and exploitation of their stored food by natural enemies, Annu. Rev. Entomol. 41, 257-286.

Westerkamp C. (1987) Das Pollensammeln der sozialen Bienen in Bezug auf die Anpassungen der Blüten, Thesis, University of Mainz, Germany.

Westrich P. (1989) Die Wildbienen Baden-Württembergs. Volumes 1-2, Ulmer, Stuttgart.

Westrich P., Schmidt K. (1986) Methoden und Anwendungsgebiete der Pollenanalyse bei Wildbienen (Hymenoptera, Apoidea), Linzer Biol. Beitr. 18, 341-360.

Zanden G. van der (1986) Untersuchungen an einigen wenig bekannten Osmia- und Megachile-Arten, mit Beschreibung zweier neuer Taxa, Reichenbachia $24,65-74$.

Zanden G. van der (1992) Neue oder unvollständig bekannte Arten paläarktischer Bauchsammler (Hymenoptera Aculeata, Apoidea, Megachilidae), Linzer Biol. Beitr. 24, 65-74.

Zanden G. van der (1996) Neue Arten und Synonyme bei paläarktischen Bauchsammlern (Hymenoptera aculeata, Apoidea, Megachilidae), Linzer Biol. Beitr. 28, 883-895.

Zanden G. van der (1998) Neue paläarktische Arten aus der Familie der Megachilidae (Insecta, Hymenoptera, Apoidea), Linzer Biol. Beitr. 30, 523527.

Zander E. (1935) Beiträge zur Herkunftsbestimmung bei Honig. I. Pollengestaltung und Herkunftsbestimmung bei Blütenhonig, Verlag der Reichsfachgruppe Imker e. V., Berlin. 